Radosław Grześkowiak @i) https://orcid.org/0000-0002-6160-9982 University of Gdańsk polrg[at]univ.gda.pl

Jakub Niedźwiedź @ịttps://orcid.org/0000-0003-4472-8151 Jagiellonian University in Kraków jakub.niedzwiedz[at]uj.edu.pl

\title{
Unknown Polish Subscriptions to the Emblems of Otto van Veen and Herman Hugo: A Study on the Functioning of Western Religious Engravings in the Old-Polish Culture ${ }^{\star}$
}

\begin{abstract}
The Seweryn Udziela Ethnographic Musem in Cracow holds an impressive collection of old engravings, among which there are also copperplates by Cornelis Galle. He used selected prints from Amorum emblemata (1608) and Amoris divini emblemata (1615) by Otton van Veen and Pia desideria (1624) by Herman Hugo to create his own emblematic cycle on metaphysical relations between the Soul and Amor Divinus.
\end{abstract}

* Publication of this paper was financed by the Ministry of Science and Higher Education of the Republic of Poland under the grant 643/P-DUN/2018. Polish version: R. Grześkowiak, J. Niedźwiedź, "Nieznane polskie subskrypcje do emblematów religijnych Ottona van Veen i Hermana Hugona. Przyczynek do funkcjonowania zachodniej grafiki religijnej w kulturze staropolskiej”, Terminus 14 (2012), issue 25, pp. 47-68. 
The drawings from the works of Veen and Hugo were very popular in the seventeenth century and inspired numerous poets and editors around Europe. In the Polish-Lithuanian Commonwealth, it was Hugo's Pia desideria that aroused particular interest. The cycle was imitated and translated by e.g. Mikołaj Mieleszko SJ, Zbigniew Morsztyn, Aleksander Teodor Lacki, and Jan Kościesza Żaba. On three of Galle’s prints stored in the Cracow museum, an anonymous author wrote epigrams, unknown until now, that accompany the images taken from the cycle by Veen (no. 8 and 21) and by Hugo (II 5). This emblematic microcycle was, with all probability, written down at the end of the seventeenth or at the beginning of the eighteenth century by a nun or a monk in one of the Lesser Polish convents or monasteries. Possibly, the origins of the cycle may be linked with the Carmelite convent in Cracow. And whether it is the actual place where the cycle was created or not, it is a good point to begin studies on the employment of emblematic practices in Catholic convents and monasteries in the Polish-Lithuanian Commonwealth from the sixteenth to the eighteenth century. Imported copperplates and woodcuts were a typical piece of the equipment of a cell. They were hung on the cell walls or were simply collected in sets of prints and often exchanged as gifts among nuns or monks, e.g. on the occasion of the New Year (an example of such a gift from 1724 is given in this paper). It was a common practice to write notes of diverse character on the reverse side of such prints, e.g. autobiographic details, short prayers or excerpts from sacred texts and religious literature. Still, the main purpose of the emblems was their application in everyday meditations and other forms of personal prayers. The three subscriptiones in the Ethnographic Museum in Cracow are also prayers of this kind, combining word and image.

Keywords: Otton van Veen, Herman Hugon, Western sacred engravings, emblems, Ethnographic Museum in Cracow

In 1615, a collection by Otto van Veen (1556-1629) was published. Its title was Amoris divini emblemata. A few years earlier, van Veen, a popular painter and graphic artist with a thorough humanistic education, had published Amorum emblemata (1608), devoted to the unruly Cupid. It turned out, however, that these emblems could be read through more than the prism of frivolous eroticism. In a short foreword Ad Lectorem et Spectatorem, the artist confessed that the originator of the collection was Infanta Isabella Clara Eugenia (1566-1633), 
who often commissioned van Veen as a painter. The future governor of the Spanish Netherlands, but also the future nun of the order of St Clare, drew the artist's attention to the fact that the moralistic texts focused on the pranks of Cupid published seven years earlier could easily be changed into the apology of Amor Divinus. ${ }^{1}$

Indeed, a number of illustrations in the Amoris divini emblemata unambiguously refer to the drawings from the earlier collection. The sixty emblems feature a winged girl as the Human Soul and a winged boy with wings, a halo, and a small bow, as God's Love. Their metaphysical adventures were a counter-reformation interpretation of the mythical theme of Cupid and Psyche. Focused on love to God and a personal religious experience, the cycle appealed with extraordinary force to the collective imagination of the time, launching an avalanche of emblematic volumes devoted to this couple, whose success did not diminish until the end of the eighteenth century. ${ }^{2}$

His fame was soon overshadowed by the carefully prepared volume of a Jesuit, Herman Hugo (1588-1629), published in 1624 under the title Pia desideria. Hugo arranged the emblems into three books according to the Ignatian division of spiritual development into three stages, namely purification, enlightenment, and unification. The work, popularised on the one hand by numerous reprints and refacimentos, and on the other by dozens of adaptations and translations into vernacular languages, enjoyed great interest in the Polish-Lithuanian Commonwealth. ${ }^{3}$ One of its translations from before 1671 was made

1 O. Vaenius, Amoris divini emblemata, Antwerp 1615, p. 4. Cf. also: S. L. Sebastián, "La visión emblemática del amor divino según Vaenius", Cuadernos de arte de la Fundación Universitaria Española 2 (1985), pp. 3-51; M. Thøfner, "Let your desire be to see God': Teresian Mysticism and Otto van Veen's Amoris Divini Emblemata”, Emblematica 12 (2002), pp. 83-103; A. Buschhoff, Die Liebesemblematik des Otto van Veen. Die "Amorum Emblemata“ (1608) und die „Amoris Divini Emblemata“" (1615), Bremen 2004, pp. 179-258.

2 See e.g. Buschhoff, Liebesemblematik, pp. 151-178, 263-267.

${ }^{3}$ On the subject of the literary reception of Hugo's collection in Europe and Poland, cf.: R. Grześkowiak and J. Niedźwiedź, "Wstęp”, in M. Mieleszko, Emblematy, ed. R. Grześkowiak and J. Niedźwiedź, Warsaw 2010, pp. 21-33. 
by the Court Marshal of the Grand Duchy of Lithuania Aleksander Teodor Lacki. ${ }^{4}$ It was published for the first time two years later, and its Cracow typographer provided some of its copies with reprints of original copperplates imported from the Netherlands. In 1744, the Minsk Voivode Jan Kościesza Żaba ${ }^{5}$ issued a new Polish version of the collection, and almost a century later, another free translation was prepared by Father Bonifacy Ostrzykowski. ${ }^{6}$ It should be added that Lacki was not the first author to become interested in the Polish language adaptation of the emblematic bestseller. As early as 1657, the court chaplain of Katarzyna Zasławska-Ostrogska (a year later Radziwiłłowa), the Jesuit Mikołaj Mieleszko, explained to his reader:

And since a certain man undertook to translate into Polish the poems of the already mentioned Father Hugo, I decided to leave this task to him and to describe in Polish verse, to the best of my capabilities, only picturae and lemmas drawn from the Holy Scriptures, as well as the message of their author. ${ }^{7}$

${ }^{4}$ Cf.: B. Pfeiffer, “'Pobożne pragnienia' Aleksandra Teodora Lackiego - pierwszy polski przekład utworu emblematycznego Hermana Hugona Pia desideria", Ze Skarbca Kultury 44 (1987), pp. 9-43; K. Mrowcewicz, "Wprowadzenie do lektury", in A. T. Lacki, Pobożne pragnienia, ed. K. Mrowcewicz, Warsaw 1997, pp. 9-12. Contrary to what both authors write (Pfeiffer, "Pobożne pragnienia' Aleksandra Teodora Lackiego", pp. 17-18; Mrowcewicz, "Wprowadzenie”, p. 8), Lacki's translation was pressed only twice, in 1673 and 1697, and the second edition sold so poorly that after four decades, that is in 1737 , it was again on the market with a new title card. The editions from 1674, 1691 and 1774 are sometimes mistakenly recorded by bibliographers (cf. P. Buchwald-Pelcowa, "Typologia polskich książek emblematycznych", Barok 3 (1996), no. 1, p. 71). See J. Hałoń, "W poszukiwaniu źródeł inspiracji, czyli o dwóch polskich wersjach Pia desideria Hermana Hugona", Roczniki Humanistyczne 50 (2002), no. 1, pp. 127-159; J. Hałoń, "Wobec obrazu", Zeszyty Naukowe KUL 46 (2003), no. 1-2, pp. 33-61; a preliminary analysis of the style of Lacki's translation: F. Dietz, E. Stronks, and K. Zawadzka, "Roomskatholieke Pia desideria bewerkingen in internationaal perspectief", Internationale Neerlandistiek 47 (2009), no. 3, pp. 31-49.

${ }^{5}$ Żaba's translation had two editions, an anonymous one published in Supraśl in 1744 and a signed one issued a decade later in Vilnius (cf. M. CubrzyńskaLeonarczyk, Katalog druków supraskich, Warsaw 1995, p. 67: no. 134; BuchwaldPelcowa, "Typologia", p. 71).

${ }^{6}$ H. Hugo, Pobożne pragnienia, transl. B. Ostrzykowski, Warsaw 1843.

7 Mieleszko, Emblematy, pp. 76-77. 
The translation Mieleszko mentioned is unknown today. Luckily, however, his work, Nabożne westchnienia [Pious Sighs], which, according to Mieleszko's declaration, contains authorial subscriptiones written to Hugo's picturae and lemmas, survived in two editions. To complete this short review of old-Polish adaptations of emblematic collections, we should mention the emblematic cycle of Zbigniew Morsztyn, also commissioned by Katarzyna Radziwiłłowa. The eclectic volume of the anonymous Capuchin Les emblèmes d'amour divin et humain ensemble, which became the basis for one hundred and thirteen lyrical subscriptiones, was also largely inspired by the emblems in Pia desideria. ${ }^{8}$

Against the background of the old-Polish popularity of Hugo's collection, the lack of interest in the pious volume of Vaenius, which was Hugo's most important inspiration, is striking. There is, however, an exception of a dozen or so emblems that were adapted into Polish only because the French Capuchin included them in the collection suggested to Morsztyn by Princess Katarzyna, who ordered the poet to add Polish subscriptiones to them. The Jesuit emblematic books that expose the theme of a tender bridal love rooted in the Song of Songs were clearly distant from the collection of 1615, which was ideologically too close to the earlier erotic book Amorum emblemata. This is why the discovery we made in the Cracow Ethnographic Museum, conducting a search prior to the preparation of the critical edition of Mieleszko's emblems, is extremely interesting.

\section{II}

Pious emblematic volumes owed their popularity mainly to illustrations. Hence, no wonder that some of them could take the form of albums that contained copperplates alone. The prints from the first edition of

${ }^{8}$ Z. Morsztyn, Emblemata, ed. J. Pelc and P. Pelc, Warsaw 2001. 
the aforementioned collection of the Capuchin issued in 1631 were accompanied by French subscriptiones written in three versed quatrains. ${ }^{9}$ But later reprints consisted only of copperplate prints, accompanied only by Latin lemmas and French distiches, which were the only literary commentary to the picturae. Zbigniew Morsztyn used such an edition of the collection, composed only of emblematic illustrations. Writing his Emblemata, he could therefore count only on his own creativity.

Emblematic engravings, however, did not need to appear in a book in order to reach the audience. Equally popular were loose copperplate prints, sometimes combined in larger cycles. The literary reception of one of them is the subject of this paper. It is a series of at least twenty-two prints kept in the Ethnographic Museum in Cracow under the working title Amor Divinus. ${ }^{10}$ The modest-sized copperplate prints (about $46 \times 60 \mathrm{~mm})^{11}$ have not only a common theme, but also a similar style. The illustrations are horizontally oriented, some of them have a title written at the top with capital letters following the source, and all of them have a lemma, as well as the same engraver's signature (the latter partly cut on some copies).

The collection, which by definition is a bundle of loose, unnumbered pictures, is difficult to characterise. First of all, it is not known

${ }^{9}$ Karel Porteman was inclined to identify the anonymous compilator of the collection, signed on the frontispiece as "un Père Capucin", with Philippe de Vilers, later Capuchin Luis de Louvain (J. Pelc and P. Pelc, "Wstęp", in Morsztyn, Emblemata, p. VII).

${ }_{10}$ The Seweryn Udziela Ethnographic Museum in Cracow, inventory nos $44813-44819,44821-44825,4489,44831-44836,44838-44845$. Some of the illustrations in the museum's collection are in two or even three copies, hence twenty-nine prints of twenty-two copperplates. The prints have survived in a varied condition (several of them are almost completely effaced, one has been coloured). The authors would like to thank Ms Beata Skoczeń-Marchewka, the senior curator from the Ethnographic Museum in Cracow, for her comprehensive help. The reproduction of the prints was possible by courtesy of the Museum. We would also like to thank Magdalena Górska for a number of useful remarks and suggestions.

${ }_{11}$ The dimensions of individual engravings vary only slightly: $43 / 46 \times 60 / 63 \mathrm{~mm}$. The printed sheets were generally cut to $60 / 65 \times 85 / 95 \mathrm{~mm}$. 
whether it has survived as a complete set. Just as some prints were bought in two or even three copies for the museum collections, others may be missing. The second difficulty is the separation of the engravings that belong to the cycle from the others. They are identified on the basis of the author's signature and style, partly also the common sources. However, even such a tightening of the criteria does not remove all doubts. ${ }^{12}$

The series is based on illustrations from three emblematic collections. The basic source was illustrations of Amoris divini emblemata (emblems 6, 8, 13, 21, 24-25, 30, 33, 38-39, 43, 46, 51, 53-54) and Pia desideria (emblems I 10, II 5, 12, III 2-3). In addition, two engravings of the cycle are modelled on the emblems from the earlier collection of Otto van Veen, Amorum emblemata $(23,93)$. This is particularly striking in the case of the print modelled on the latter emblem. The print in the discussed series repeats the motto from the letters of Seneca the Younger: Si cruci affigatur, si igni comburatur, semper amat qui vere amans est ["Even if nailed to a cross or burned with fire-who loves truly, loves steadily"]. This emblem has its counterpart in the later pious volume of Vaenius (Amoris divini emblemata, 35), where this motto is also repeated, but the pictura itself is clearly different, so there is no doubt where the compiler of the cycle got it from. ${ }^{13}$

In book editions, the two emblematic collections glorifying Amor Divinus, by Otto van Veen and Herman Hugo, were combined only at the beginning of the eighteenth century. This was the case with the French version of L'ame amante de son Dieu from 1717, the German

12 For example, a print stored in the Museum in two copies, signed like the others with "C. Galle" with the motto: Sit in amore reciprocatio, which imitates an illustration from Amoris divini emblemata (13), is unlikely to be part of the cycle as it is the only one vertically oriented, and the hand of the motto, imitating a sweeping handwriting, clearly differentiates it from the others (Ethnographic Museum in Cracow, inventory nos 44846 and 44847).

13 The Ethnographic Museum in Cracow, inventory no. 44829; O. Vaenius, Amorum emblemata, figuris aeneis incisa, Antwerp 1608, pp. 184-185; Vaenius, Amoris divini emblemata, pp. 76-77. 
version of Die Ihren Gott liebende Seele from 1719, or the Dutch version of Jan Suderman De godelievende ziel from 1724, which were repeatedly reissued. ${ }^{14}$ But the selected emblems from the two collections were combined more often, as in the compilation collection of the Capuchin from 1631. The author of the cycle did a similar thing. In the book in which the emblematic illustration is accompanied by a literary work, identifying the character in the pictura is not difficult as the text explains to which couple the collection is devoted. However, in Amoris divini emblemata, both characters were signed in the first emblem in which they appear: Amor divinus and Anima. Since the book illustrations in the discussed cycle have become independent prints, each of which could exist on its own, such descriptions are repeated on most of the engravings. What is significant, however, is that this pertains only to the prints whose source were the emblems from Amoris divini emblemata, as there are no such comments on the picturae modelled on the illustrations of Pia desideria and Amorum emblemata. Moreover, only the counterparts of emblems from Amoris divini emblemata were provided with a title, taken from the iconographic original.

Although the author of the cycle took care to sign the engravings, their identification and determining the relative date of the creation of his work is still difficult. The common signature on the engravings, "C. Galle", should be deciphered as Cornelis Galle. The problem is that not only the profession, but also the name and form of the signature were inherited by three generations of the Antwerp Galle family: father, son, and grandson. The most famous was Cornelis I Galle (1576-1650), a copyist of the works of Rubens and author of frontispieces for books printed in Officina Plantiniana (among others, for the edition of Mikołaj Kazimierz Sarbiewski's collected poems from 1632, also according to the design of Rubens). ${ }^{15} \mathrm{He}$ was also the

${ }^{14}$ Cf. P. M. Daly and G. R. Dimler, The Jesuit Series, vol. 3, Toronto 2002, pp. 179-185: J.694-J.697; pp. 230-233: J.743-J.745; pp. 164-173: J.684-J.688.

15 Cf. J. A. Chrościcki, "Horatius Sarmaticus. Dwa antwerpskie wydania Lyricorum Sarbiewskiego z frontyspisami według projektów Rubensa”, in O ikonografii świeckiej doby humanizmu. Tematy - symbole - problemy, ed. J. Białostocki, War- 
author of emblematic illustrations for the famous work by Benedict van Haeften Regia via crucis from 1635. However, the cycle in question was not prepared for a choosy recipient, and the quality of the prints is rather poor. They could have been produced by Cornelis II Galle (1615-1678) or his son Cornelis III Galle (1642-1678/1679), both of whom were involved in the profitable production of devotional prints and signed them, as did their father and grandfather, "C. Galle". ${ }^{16}$ The cycle was created in the years 1624-1679, most probably in the second half of the seventeenth century.

Galle's cycle is only a modest part of an extremely valuable collection of nearly 1500 loose prints from the seventeenth-nineteenth centuries, purchased by the Ethnographic Museum in 1968. The Discalced Carmelite Father Mieczysław Kluz (Fr Władysław of the Birth of Holy Mary, 1925-1995) was an intermediary in the purchase. ${ }^{17}$ For many years he was the curator of the Congregation of the Carmelite Sisters of the Infant Jesus and a confessor of the Discalced Carmelite Sisters in Wesoła in Cracow. A large part of the provenance notes on these loose prints indicate that they come from the monastery in Wesoła. Some others were made by monks, so it is not entirely clear whether they come from a former male monastery or from the Carmelite sisters, to whom they could have been sent afterwards. Both the discussed series and the entire Cracow collection of prints constitute excellent material for research on the functioning of emblems, or more broadly devotional prints

saw 1977, pp. 281-333; J. A. Chrościcki, "Między Wilnem, Rzymem i Antwerpią. O dwóch projektach P. P. Rubensa do sześciu wydań „Lyricorum libri IV” Macieja Kazimierza Sarbiewskiego w Offcina Plantiniana”, Roczniki Humanistyczne 50 (2002), no. 4, pp. 99-126; J. A. Chrościcki, "Peter Paul Rubens a Maciej Kazimierz Sarbiewski”, Ciechanowskie Zeszyty Literackie 10 (2008), pp. 105-114.

${ }^{16}$ Cf. M. Selling, "Galle Cornelis" (1-3), in Saur Allgemeines Künstlerlexikon. Die bildenden Künstler aller Zeiten und Völker, vol. 48: Gallarini-Garcha, Munich and Leipzig 2006, pp. 8-9.

${ }_{17}$ Cf. B. Skoczeń-Marchewka, Cor Jesu Amanti Sacrum - obiekt tygodnia: kwiecień/2, http://www.etnomuzeum.eu/Obiekty,6_cor_jesu_amanti_sacrum_ obiekt_tygodnia_kwiecien2.html (accessed on 1 Jan. 2011). 
(as only a small part of the engravings is emblematic in nature), in the monastic environment of the Polish-Lithuanian Commonwealth. The rules of some convents strictly defined the presence of such drawings in a cell: for example, the Norbertines could only hang one. ${ }^{18}$ There are old portraits of nuns or monks in their cells, where the only decoration is an unframed copperplate print behind them. ${ }^{19}$ Even if the rule determined the number of engravings on the cell wall, monks and nuns usually had more such graphic aids to pray or meditate. Such use of engravings is not limited to monastic environments.

\section{III}

Early-modern devotional prints, mass-produced and reproduced, were used for catechesis as an equivalent of today's sacred pictures. Initially, this role was played by cards with patristic quotations, particularly keenly distributed by Jesuits to the faithful for contemplative purposes. In a print published in 1582, a member of the Protestant Community of the Polish Brethren Marcin Czechowic mocked the practices of the Society of Jesus:

... who teach people using not the true Word of God but beguiling them with fairy tales, those maxims written on little cards that they send to the faithful ... probably so that their maidens and women do not forget them because they send most such things to ladies. ${ }^{20}$

18 See M. Borkowska, Życie codzienne polskich klasztorów żeńskich $w$ XVIIXVIII wieku, Warsaw 1996, p. 129.

19 See, for example, the oil painting by José Mariano del Castillo, the Portrait of Sister Maria Clara Josepha from the last third of the eighteenth century or the anonymous Portrait of Francis of Saint Anne from around 1754 (Museo Nazional de Arte, Mexico).

${ }^{20}$ M. Czechowic, Zwierściadłko panienek chrystyjańskich, ed. K. Meller and D. Chemperek, Warsaw 2011, p. 57: I 3,8. 
These pieces of paper were soon to feature illustrations beside a biblical or patristic sentence. Francis Borgia, the third general of the Society of Jesus, introduced the custom of choosing a saint, to whom one directed his or her prayers in the coming month, which was done by drawing cards with a saint's image and pious motto. This custom was cultivated not only in religious orders and congregations. At the end of the sixteenth century, it was also introduced at the royal court by Anne of Austria (1573-1598), wife of Sigismund III, known for her pious practices:

She and her whole court had a custom of choosing by way of allotment or drawing of lots a random saint at the beginning of each month. In her last month of life, February, St Scholastica happened to be her patron with the following maxim: Memento homo, quia pulvis es et [in pulverem reverteris]"Remember, man, dust you are and unto dust you shall return". Therefore, having fallen ill, she always had this card before her eyes and prepared herself for death by receiving the sacraments. ${ }^{21}$

A quarter of a century later, the Crown Master of the Horse Krzysztof Zbaraski mentioned a similar draw held by the Franciscans in his account of his diplomatic mission to the Ottoman Empire conducted in 1622-1623:

... on the New Year's Day, my chaplain went to Galata to his co-friars of St Francis and there he chose a sorte card, as is their custom, with a patron saint for the coming year. For me, too, he drew St Michael with this sentence: Guardati da poco barbarico colore, Che nel mondo non fu peggiore. ${ }^{22}$

In a poetic narration of these events by Samuel Twardowski, before the meaning of the motto and engraving on the selected card

${ }^{21}$ J. Kwiatkiewicz SJ, Roczne dzieje kościelne od Roku Pańskiego 1198 aż do lat naszych, Kalisz 1695, p. 802. Cf. also: J. Muczkowski, Bractwa jezuickie i akademickie w Krakowie, Cracow 1845, pp. 52-53, footnote 15.

22 "Relacyja poselstwa księcia Zbaraskiego do Turek in Anno 1623", in L. Rogalski, "Poselstwo Krzysztofa księcia Zbaraskiego do Turcji w roku 1622”, Dziennik Wileński 3 (1827), p. 273 (as cited in S. Twardowski, Przeważna legacyja Krzysztofa Zbaraskiego od Zygmunta III do soltana Mustafy, ed. R. Krzywy, Warsaw 2000, p. 340). 
was interpreted in detail, the poet vividly described the image of the patron of the month:

The day before the chaplain of this princely family

Attends the customary drawing

Of cards with patrons, which the superior hands out

To his monks at the beginning of each month,

He first puts them all in a big bowl

From which he draws and distributes them one by one. These cards feature A patron saint for them and a virtue

Which they should practice. ${ }^{23}$

In both cases, the fact that these images were drawn was considered as boding: the queen died on 10 February, on the day of St Scholastica, whose image she contemplated just before her death, and Zbaraski's card was interpreted as an allusion to the great vizier. In this way, the mass-produced prints, assigned randomly to the recipient, marked his or her personal fate. The holy patrons, whose images were on the prints, were supposed to mark an accidental choice with a metaphysical purpose.

Religious prints were personalised in a much simpler way when such a picture became a gift. One of the engravings from the abovementioned collection of the Ethnographic Museum, like the others that circulated in monasteries, bears the note "The 1724 New Year gift for Miss Katarzyna" and below a pious maxim from St Ambrose (figs 1-2). ${ }^{24}$ A similar gift was given by Father Stanisław Grochowski to Katarzyna Przerębska on the occasion of her marriage, when around 1600 she married the Starosta of Oświęcim, Piotr Komorowski (1580-1640). The visual representation of the Passion of Christ (Grochowski does not specify whether it was a painting or a print) was accompanied by a verse dedication, which he later included in his collected poetic writings entitled $\mathrm{Na}$ obraz Męki Pańskiej za kolędę

23 S. Twardowski, Przeważna legacyja, p. 120: III, ll. 1085-1092.

${ }^{24}$ A print in the collection of the Ethnographic Museum in Cracow, inventory no. 44959. The name and surname of the nun who received the gift was scratched out. 

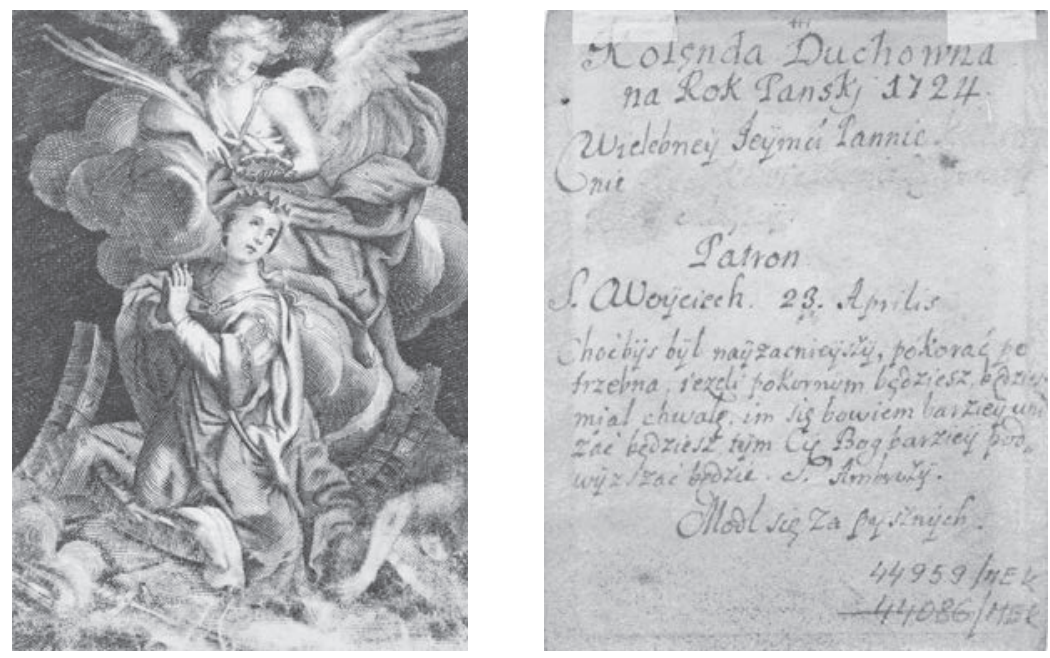

Figs 1-2. Copperplate depicting St Catherine, given to sister Katarzyna <. . .>owiczówna on the New Year's Day 1724. Ethnographic Museum in Cracow, inventory no. 44959

świętokatarzyńską od spowiednika darowany p[annie] młodej [On the image of the Passion of Christ given to the Bride by her confessor]:

This New Year's gift is presented to

Katarzyna Przerębska, of noble birth,

Who tied the holy knot with Komorowski,

To be kept in pious memory.

So that this image of Crucified Christ

Replaced her previous teacher.

So that, as Christ suffered a great deal on his cross,

She would now be ready to endure her fate.

Matrimony entails many crosses,

But when one looks with their heart at the sorry cross

Of the Lord, they never cease on

Their own cross because Christ supports them. ${ }^{25}$

25 S. Grochowski, Wiersze i inne pisma co przebrańsze, ed. K. J. Turowski, Cracow 1859, p. 236: 11. 1-12. 
Here the picture offered to the former penitent was to replace the confessor in the daily reminder that the marriage cross should be born with dignity and acceptance. So again, it became an artefact marking the way of life according to the recommendations verbalised, for example, in Dominican Fabian Birkowski's sermon:

Therefore, Christ as described before your eyes, is painted in you, that is, crucified before you .... The image of the crucified [Christ] is then like a book written with nails, thorns, whips, javelins instead of quills, and blood instead of ink. In this book, we can read about how we should despise sins or glorify and love Christ, our Saviour. ${ }^{26}$

It is worth remembering that in extreme cases a print was also a subject of worship, as shown by the example of the Miedniewice woodcut, with a holly image of the Holy Family from Studzianna, painted on the basis of an engraving by Jacques Callot from around $1628 .^{27}$

This brings us to another, perhaps the most important aspect of the reception of religious prints. Their artistic qualities were appreciated by the users, who oftentimes coloured or painted the black-and-white engravings. ${ }^{28}$ They became the most important medium through which Western counter-reformation art and its iconographic devices penetrated the Polish-Lithuanian Commonwealth. The prints imported from Denmark, Germany or France were most often the inspirations for the creation of Polish religious paintings (sometimes also sculptures) in the seventeenth and eighteenth centuries, also in churches and monasteries on the outskirts

${ }^{26}$ F. Birkowski, "O świętych obrazach, jako mają być szanowane, kazanie", in F. Birkowski, Głos krwie B. Jozafata Kuncewicza, Cracow 1629, pp. 73-74.

${ }_{27}$ M. Walicki, "Ludowy refleks sztuki Callota", in M. Walicki, Obrazy bliskie i dalekie, Warsaw 1972, pp. 252-264.

${ }^{28}$ Some of the engravings from the vast collection of the Ethnographic Museum in Cracow are coloured. In Galle's cycle discussed below, this applies, for instance, to the emblem Sollicitus est, which is an imitation of a print from Amoris divini emblemata (54; inventory no. 44817). 
of the country. ${ }^{29}$ And in large monasteries, there were quite a few works of art. In Cracow, hundreds of them survived in the Carmelite nunnery in Wesoła, and several times more in the Norbertine convent in Zwierzyniec. ${ }^{30}$ The monastery's artistic reception of foreign models took on a variety of forms. In the second half of the seventeenth century, Warsaw's Visitants embroidered altar frontals modelled on emblematic illustrations, ${ }^{31}$ and in 1644, Father Stanisław of Stolec decorated a large gradual presented to the Observant Carmelites in Cracow with numerous miniatures faithfully reproducing Antwerp engravings. ${ }^{32}$

The adaptation of emblematic illustrations for catechesis increased the attractiveness of these holy pictures. The interaction of images and mottos made it easier to use an engraving intended for prayerful contemplation. Most often used as a bookmark for religious books, it could also serve as a place to write an autobiographical note or, more often, a declaration or recommendation concerning religious practices or prayer (on the margin or on the reverse side of the print). For example, the owner of a print by Cornelis Galle that was a copy of an emblem from Amoris divini emblemata (13) wrote on the reverse side the prayer of St Gertrude:

${ }^{29}$ Among recent works on this subject, cf. e.g. K. Moisan-Jabłońska, Obrazowanie walki dobra ze złem, Cracow 2002, pp. 16-20; Inspiracje grafikq europejska w sztuce polskiej. Czasy nowożytne, ed. K. Moisan-Jabłońska and K. Pomian, Warsaw 2010.

30 Borkowska, Życie codzienne polskich klasztorów, p. 129.

31 G. Ławniczak, "Emblematy haftowane symbolizujące życie św. Franciszka Salezego na barokowych antependiach z kościoła SS. Wizytek w Warszawie”, Barok 8 (2001), no. 2, pp. 59-73. The study in its main part concerns emblematic embroidery from before 1757, but it also mentions some earlier ones.

32 Graduał karmelitański z 1644 roku o. Stanisława ze Stolca, ed. T. Chrzanowski and T. Maciejewski, Warsaw 1976. Although the author of the iconographic introduction put forward a thesis that the miniatures adorning the codex depend on a graphic original, he could not support it with a concrete example (ibid., p. 29). Several of them were identified by Krystyna Moisan-Jabłońska (Obrazowanie, pp. 41-42 and figs 6 and 8, pp. 309-310 and figs 258-260, pp. 378-379 and figs 307 and 309, pp. 409414 and figs 323-324), and they can be supplemented with a number of further ones. 
To be repeated on the Ascension Day two hundred and twenty-five times (one and a half rosaries and two tens and five beads): "Come, Jesus, the Bridegroom blossomed in cheerfulness and one who ascended into heaven. I greet and worship you, the only consolation of my soul. Amen" ${ }^{33}$

These strictly practical notes sometimes took on a literary form. Poems written about paintings had a glorious tradition in Polish literature, dating back to the Renaissance neo-Latin poetry. In Poland, they were created on a larger scale by Mikołaj Rej or Mikołaj Sęp Szarzyński, ${ }^{34}$ and at the end of the seventeenth and in the eighteenth centuries, literate women were also interested in it. These were not only anonymous nuns, but also poets like Antonina Niemiryczowa, who wrote numerous rhymed subscriptiones to religious pictures (for example, Pod obrazem N[ajświętszego] Sakramentu, przy którym ś[więty] Franciszek i Antoni, Pod Wniebowzięciem Maryi, Pod P[anem] Jezusem Bolesnym [A the painting of the Holy Sacrament, with St St Francisc and Anthony nearby, under the Assumption of Mary, under the Man of Sorrows]), but also to sentimental scenes (for example, Pod kawalerem z dama, której piesek koszulki podejmuje [Under a young man with a lady whose little dog bites on a shirt]) or to ornithological illustrations (such as Pod ptakiem bekasem wielkiem [Under a large snipe], Pod ptakiem kurką wodna [Under a common moorhen]). ${ }^{35}$

${ }^{33}$ A print in the collection of the Ethnographic Museum in Cracow, inventory no. 44846.

${ }^{34}$ Cf. J. Pelc, Słowo i obraz. Na pograniczu literatury i sztuk plastycznych, Cracow 2002, pp. 62-119, 142-146.

${ }^{35}$ [Zbiór] wierszów polskich kompozycyj ..., które się w pokojach złotyjowskich znajduja pod temi figurami, które się niżej wyrażaja, d[ie] 6 Julii, Anno Domini 1753 (MS 5284/I in the collection of the Ossolineum in Wrocław-this is a copy of Wiktor Gomulicki from 1896, which we could use thanks to the courtesy of Magdalena Górska). Cf. also: W. Gomulicki, "Zapomniana poetka polska z wieku XVIII-go”, in W. Gomulicki, Kłosy z polskiej niwy, Warsaw 1912, pp. 289-384; A. Roćko, "Wizerunek artystyczny Antoniny Niemiryczowej", in Pisarki polskie epok dawnych, ed. K. Stasiewicz, Olsztyn 1998, pp. 129-140. In the commentaries, Niemiryczowa's poems on the images (icones) are mistakenly called emblems, notwithstanding the fact that among her subscriptiones only one is provided with a translation of the 
The prints of engravings from Western workshops have sometimes inspired literary undertakings of a much higher quality. The academic editor of the valuable series Polska Sztuka Kościelna Renesansu i Baroku. Tematy i Symbole, Krystyna Moisan-Jabłońska, when planning it, declared that she would take into account religious literary texts, which remained in the same circle of influence as sacred art. And she made the following reservation: "Apart from exceptional cases, the works of Baroque poets were deliberately omitted, as generally intended for a narrower and more elite audience". ${ }^{36}$ The fundamental mistake of such an assumption is that, although the quality of literary works by mediocre poets, and thus their reception, is different from that of the Church's functional literature, the attitude of litterateurs towards works of art is exactly the same as that of much less talented writers. Here are two salient examples. According to the title declaration, an early poem by Wacław Potocki, Pojedynek rycerza chrześcijańskiego wierszem opisany, które pod obrazem tegoż rycerza położone, dziwnie quadrant $i$ rapiunt animum $i$ oczy lectoris et spectatoris [A duel of a Christian knight described in verse, which laid under the image of this knight, strangely quadrant and rapiunt animum and the eyes lectoris et spectatoris], gives first a description and then a detailed lecture on an engraving by Hieronymus Wierix modelled on the design of Maarten de Vos (or its copy) entitled Spirit [u]ale Christiani militis certamen, which affects the recipient of both the visual representation and the quotations from the Bible that describe each element of the pictura. ${ }^{37}$ Years later, the author will give a description of the same

popular Latin motto: "Your death-my life, your wounds-my salvation" (Przy zwierciadle do Jezusa ukrzyżowanego, przy którym Śmierć $i$ Czas; At the image of Crucified Jesus accompanied by Death and Time).

${ }^{36}$ Moisan-Jabłońska, Obrazowanie, p. 10. See also former declarations: K. Moisan-Jabłońska, "Uwagi nad metodologią badań ikonografii sztuki kościelnej dobry kontrreformacji", Biuletyn Historii Sztuki 50 (1988), no. 4, pp. 335-340; K. Moisan-Jabłońska, "Wprowadzenie", in M. Pielas, Matka Boska Bolesna, Cracow 2000, pp. 5-13.

${ }_{37}$ W. Potocki, Pojedynek rycerza chrześcijańskiego, MS 5888/I in the Library of the Ukrainian Academy of Sciences (collection of Ossolineum), pp. 874-880 
engraving in the poem Rozbój duchowny na drodze zbawiennej [The spiritual struggle on the way to salvation $].^{38}$ Kasper Twardowski also included a number of scenes and descriptions of personifications in the poem Łódź młodych [The bout of the young] from 1618, making it clear that they were based on copperplates printed on leaflets-as in the case of the seven deadly sins, where envy "engraved in copper ... had the following title: 'INVIDIA". For example, the Pieśn do Bogarodzice [The song to the Mother of God] published there gives a faithful poetic description of a popular engraving by Hieronymus Wierix and its Latin lemma. ${ }^{39}$

Not only recognised poets used emblematic engravings for literary purposes. This was much more often the case for anonymous or, at best, little-known writers. Such a practice was particularly common in monastic circles, where copies of poetic mottos were often decorated with loose engravings pasted into manuscripts. Foreign and domestic examples of such use of the emblematic prints from the Cor Iesu amanti sacrum cycle by Anton II Wierix have been discussed in a different study. Two different literary arrangements of the cycle with pasted illustrations have survived in the book collection of the Norbertine

(edition in J. T. Trembecki, Wirydarz poetycki, ed. A. Brückner, vol. 2, Lviv 1911, pp. 74-78); Hollstein's Dutch and Flemish Etchings, Engravings and Woodcuts 14501700, vol. 66: The Wierix Family, part 8, comp. Z. van Ruyven-Zeman and M. Leesberg, ed. J. van der Stock and M. Leesberg, Rotterdam 2004, p. 136: no. 1796/I. See also: Moisan-Jabłońska, Obrazowanie, pp. 309-310 and figs 258-260.

${ }^{38}$ W. Potocki, Rozbój duchowny na drodze zbawiennej, MS IV.3047 in the National Library in Warsaw, ff. 182v.-183r. (edition in J. Malicki, "Wacława Potockiego Rozbój duchowny", in Miscellanea staropolskie, vol. 5, ed. T. Ulewicz, Wrocław 1980, pp. 247-248: 11. 203-222).

${ }^{39} \mathrm{~K}$. Twardowski, Łódź młodzi z nawałności do brzegu plynąca, ed. R. Grześkowiak, Warsaw 1998, pp. 55-56: 11. 550-552, 775-802; Hollstein's Dutch and Flemish Etchings, p. 167: no. 1819 (nota bene, the origin of the print dated here as "before 1619 " is made more precise by Twardowski's text, completed before 11 November 1618). Cf. also: Moisan-Jabłońska, Obrazowanie, p. 462 and figs 357-358, 361. For the influence of visual representations on Twardowski's text see R. Grześkowiak, "Wprowadzenie do lektury", in K. Twardowski, Łódź młodzi, pp. 16-24 and figs 1-7. 
nuns in Imbramowice. ${ }^{40}$ In the collection of Discalced Carmelite Sisters in Cracow, on the other hand, a poetic biography of the patroness of the Order has survived, written in the form of subscriptiones to engravings pasted in the manuscript, some of which came from the series of prints entitled Vita effigiata della serafica vergine s[anta] Teresa di Gesù from 1715 or 1716 by Arnold van Westerhout (16511725). ${ }^{41}$ In Polish monastery collections, there are more such works from the seventeenth and eighteenth centuries, awaiting researchers and publishers' attention. The pious silva rerum with prayers, meditations, ejaculations or religious literary texts, written not only for the spiritual benefit of the female or male owner, but also ad maiorem Dei gloriam, is often not only smaller than the typical quarto, the standard size of a commonplace book, but also much neater. Time behind the monastery wall passed differently. There, it was possible to unhurriedly make ornamental initials, vignettes, colourful titles and frames around the text or to paste images of saints or emblematic prints. ${ }^{42}$

Polish authors did not always create their own handwritten books illustrated with loose emblems. The literary reception was often much more modest. Just as Polish rhymed subscriptiones ${ }^{43}$ were added on

${ }^{40}$ Cf. Grześkowiak and Niedźwiedź, "Wstęp”, pp. 20-21 and Mieleszko, Emblematy, pp. 333-354 (an edition of one of the cycles).

${ }^{41}$ M. Nawrocka-Berg, "Osiemnastowieczny Żywot serafickiej panny Teresy świętej ze zbiorów sióstr karmelitanek bosych”, Barok 12 (2005), no. 2, pp. 145-156. The title page of the text with the engraving pasted in it, not included in the edition, is reproduced in M. Borkowska, Panny siostry $w$ świecie sarmackim, Warsaw 2002, fig. III 4.

${ }^{42}$ Cf. Borkowska, Panny siostry, pp. 312-313.

43 To limit ourselves only to religious emblems, it is worth recalling anonymous lemmas from the beginning of the seventeenth century in Georgette de Montenay's Emblematum Christianorum centuria from 1584 (H. Keferstein and B. Wojczulanis, "Polska wersja rękopiśmienna emblematów Georgette de Montenay", Komunikaty Mazursko-Warmińskie 3 (1967), pp. 518-522); R. Pollak, "Emblematy Anonima z początków XVII w.", in Miscellanea literackie, vol. 2, ed. R. Pollak, Wrocław 1966, pp. 110-131) and Amoris divini et humani effctus varii from 1626 (Miłości Boskiej i ludzkiej skutki różne. Wraz z siedemnastowieczna polska wersją tekstów do „Amoris divini et humani effectus varii”, ed. J. Pelc and P. Pelc, Warsaw 2000). 
the margins of emblematic books, so were sometimes loose engravings. The subject of this study is poetic texts added to the engravings belonging to the discussed cycle of Cornelis Galle.

\section{IV}

On the margins of the three engravings in the compilation cycle, someone wrote four-line subscriptiones in the same hand from the beginning of the eighteenth century. These modestly sized epigrams by an anonymous monk or nun are an interesting contribution to the old-Polish reception of religious emblems of Vaenius and Hugon.

Let us start with an emblem that copies the illustration of the volume Pia desideria (II 5) and its lemma: Averte oculos meos ne videant vanitatem. Psal. 118 ["Turn my eyes away from worthless things" Ps. 118(119):37]. ${ }^{44}$ The anonymous song is the fifth known old-Polish text written to this pictura. In addition to two translations, by Lacki and Żaba, of the original subscriptio by Hugo we also have two independent poetic commentaries on the engraving and lemma of the emblem by Mieleszko and Morsztyn. ${ }^{45}$ The former two had to face the challenge of translating the sophisticated elegy from the original, which gives the exegesis of the psalmic quotation in the lemma. Using rhetorical argumentation supported by ancient, Old Testament and Christian examples, Hugo pointed to the danger of sin. The examples

${ }^{44}$ All biblical quotations are cited after The Holy Bible: New International Version, transl. and published by International Bible Society, verified edition, Nashville and London 2011, available online at biblegateway.com (accessed on 17 Oct. 2019).

${ }^{45}$ See H. Hugo, Pia desideria emblematis, elegiis et affectibus S[ancti] Patrum illustrata, Antwerp 1624, ff. L2r.-L3r. (and commentary: ff. $\mathrm{L}_{3} \mathrm{v}-\mathrm{L}_{6} \mathrm{v}$ ); Lacki, Pobożne pragnienia, pp. 88-90; H. Hugo, Pobożne pragnienia, [Polish translation by J. K. Żaba, Supraśl] 1744, ff. $\mathrm{D}_{1} \mathrm{v}-\mathrm{D}_{2} \mathrm{v}$ (another edition: H. Hugo, Pobożne żadania, transl. J. K. Żaba, Vilnius 1754, pp. 55-57); Mieleszko, Emblematy, pp. 116-117; Morsztyn, Emblemata, pp. 154-155. 
were faithfully rendered in both Polish versions, but there is little left of the lyrical artistry of the original.

Also Zbigniew Morsztyn, who used only the compilation collection without extensive subscriptiones, referred in his poetic commentary to the same examples as Wierix, also proving his knowledge of Hugo's cycle. Under Morsztyn's pen, the argumentation of Wierix turned into an amplification, and a lyrical confession replaced the original admonitions. He preferred to refer to the reader's imagination rather than his or her intellect through extensive comparisons and metaphors. Twenty years earlier, Mieleszko, who had written his own lemma, concentrated exclusively on the pictura provided with a motto (compositio loci), which was necessary to start the meditation process. The central point of the poetic commentary on the emblem is the dangers related to the World, which leads even incautious saints into temptation.

All these Polish-language subscriptiones to Hugo's emblem focused on the dangers of earthly attractions, personified in the engraving by an elegant woman. The engraved copies were characterised by a lot of inertia in this respect. However, the modifications to which the appearance of the affected lady was subjected in the imitations for the use of sacred art are significant. Such an image of the World leading into temptation can be seen in the stalls from 1662 in the chancel of St John the Baptist's church in Pilica, in the polychromies on a wall of one of the rooms in a manor house in Rdzawa, on the ceiling of a seventeenth-century church in Gvardeyskoye (then Mühlhausen, today in the Kaliningrad Oblast), and on the windowsill of the gallery from the beginning of the next century in St Catherine's church in Nowy Targ. We also know it from Pomeranian baptismal fonts in Konarzewo and Otok from the 1680s, carved by the Kołobrzeg master Martin Edleber. ${ }^{46}$ Each time, the craftsmen left the sackcloth

${ }^{46}$ M. Marcinowska, Dwór pełen barw. Architektura i dekoracja malarska dworu z Rdzawy w Sądeckim Parku Etnograficznym, Nowy Sącz 1997, p. 53 and figs 48a-b; M. Marcinowska, "Emblematy ze ścian dworu z Rdzawy w Sądeckim Parku 
robes of the Soul and Amorus Divinus unchanged, focusing their invention on the appearance of personification of worldly temptations. In each of these paintings, Lady World has a different hairstyle and a different dress, always in line with the current fashion-as ephemeral as the soap bubbles, which were supposed to be her symbol in the pictures. The artistic perception followed a path parallel to the literary reception, focusing on the attractiveness of this personification and thus on the dangers it embodies.

The message expressed in the anonymous subscriptio added the emblem is clearly different from all these works (fig. 3):

So I am running away from the vanity of the World,

I despise everything, and out of sincere gratitude

Unto thee, O Lord, do I turn the desires

Of my eyes. Establish them in my memory. ${ }^{47}$

Much more than other imitators, the author of these words enthused over the concept of application of senses, characteristic of Ignatian spirituality. Like everything else, the sense of sight can be used for both evil and godly purposes. While Hugo and his Polish imitators exposed the psalmist's message, here the positive aspect prevails: the interest in the world was questioned only in order to give oneself fully to God. The prayer apostrophes turn the short subscriptio into

Etnograficznym”, Rocznik Sądecki 37 (2009), pp. 166-167; A. Skorupa, "O obrazach na parapecie chóru kościoła św. Katarzyny w Nowym Targu”, Almanach Nowotarski 10 (2006), pp. 128-133; M. Wisłocki, Sztuka protestancka na Pomorzu 15351684, Szczecin 2005, pp. 130-132; M. Wisłocki, "Zur Rezeption jesuitischer Ideen in der evangelischen Frömmigkeit und Kirchenkunst Pommerns", in Jesuitische Frömmigkeitskulturen. Konfessionelle Interaktion in Ostmitteleuropa 1570-1700, ed. A. Ohlidal and S. Samerski, Stuttgart 2006, pp. 312-315 and figs 5-6. The full list of literature on the subject and a discussion of the reception of illustrations from Pia desideria in the art, see: Grześkowiak and Niedźwiedź, "Wstęp", pp. 37-47 and figs $29-32$.

${ }^{47}$ A print in the collection of the Ethnographic Museum in Cracow, inventory no. 44816 . 


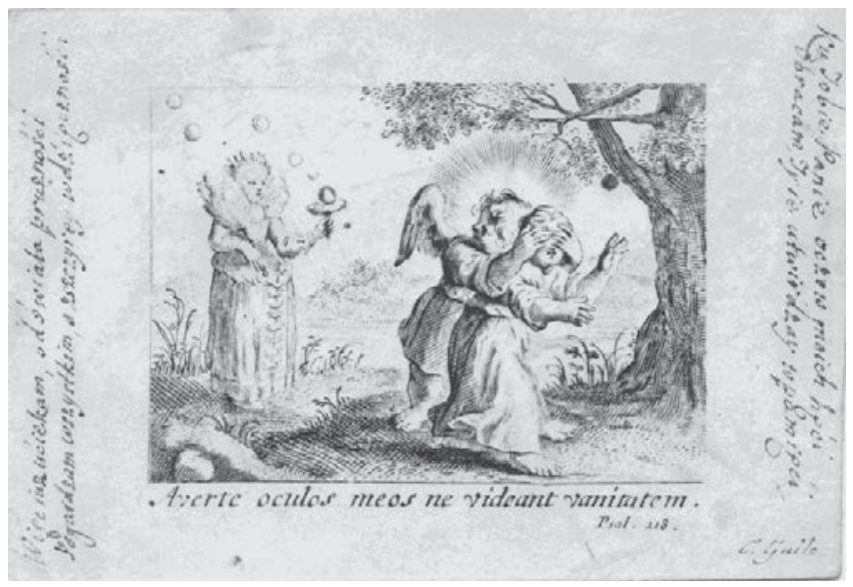

Fig. 3. A Polish subscriptio to a copperplate by C. Galle (copy of emblem II 5 from Pia desideria by Herman Hugo). Ethnographic Museum in Cracow, inventory no. 44816

an ejaculation, perfectly corresponding to the original context of the emblem, presented in the second part of Hugo's cycle, devoted to the desires of the Sanctified Soul, no longer sensitive to the temptations of the world. If, taking into account the provenance of the prints, an unknown male or female author of the four-line poems is placed in a monastic environment, the break with the World described here gains additional meaning.

Two more subscriptiones were added to the engravings of the cycle modelled on the emblems from Vaenius' Amoris divini emblemata. The protagonists of both prints are almost identical to the previous illustration and differ from their prototype in details (in the illustrations in Hugo's collection the Soul is not winged, and Amor Divinus does not have the typical armature of Cupid). The main difference that drew the attention of the author of the poetic commentaries was the fact that in engravings modelled on Vaenius' work the pair of heroes was signed: Amor divinus and Anima. The previous emblem was interpreted personally as the lyrical subject spoke in the first person directly to the merciful God. The other two epigrams, taking up the 


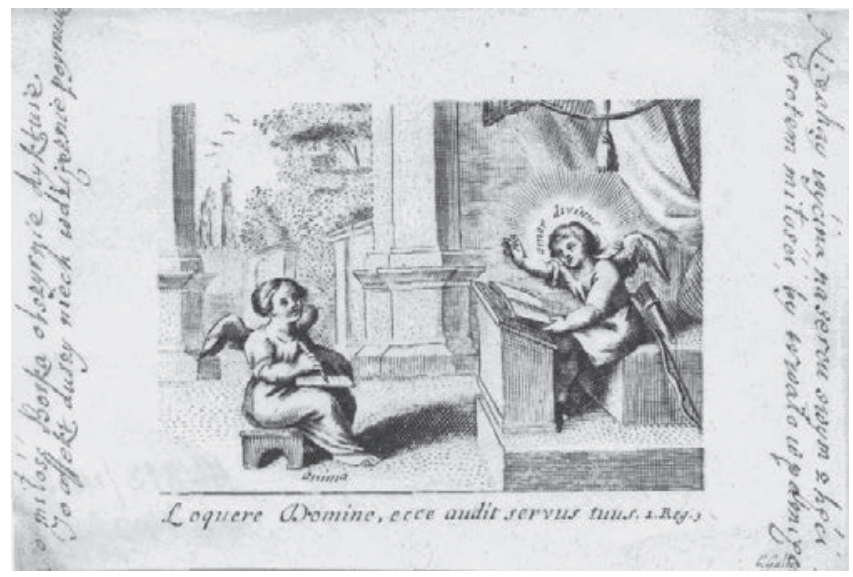

Fig. 4. A Polish subscriptio to a copperplate by C. Galle (copy of illustration of emblem 8 Amor docet from Amoris divini emblemata by Otto van Veen). Ethnographic Museum in Cracow, inventory no. 44813

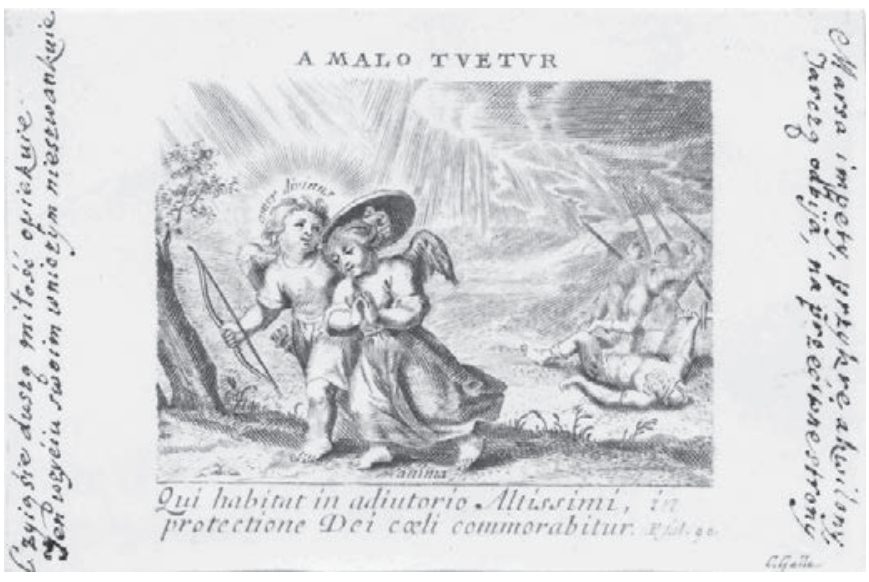

Fig. 5. A Polish subscriptio to copperplate by C. Galle (copy of illustration of emblem 21 A malo tuetur from Amoris divini emblemata by Otto van Veen). Ethnographic Museum in Cracow, inventory no. 44814 
message of the illustrations, concern the relationship between the "Soul" and the "Divine Love". A print that is a copy of the illustration of the Amor Docet emblem from Amoris divini emblemata (8), bears a biblical motto behind the source: Loquere, Domini, ecce audit servus Tuus. I Reg. 3 ["Speak, O Lord, for your servant is listening" 1 Sam. 3:9], the anonymous author noted (fig. 4):

What Divine Love dictates extensively,

The affection of the Soul should take with grace.

Let them willingly carve [these teachings] in their heart

With the spearhead of love to keep them in mind. ${ }^{48}$

The engraving A malo tuetur, on the other hand, is a copy of emblem 21 from the same collection, provided with one of the quotations cited there: Qui habitat in adiutorio Altissimi, in protectione Dei coeli commorabitur. Psal. 90 ("Whoever dwells in the shelter of the Most High will rest in the shadow of the Almighty" Ps. 90(91):1), is followed by a subscriptio added in the margins (fig. 5):

If one's Soul is under the care of Love,

Their life does not fail in anything:

They strike off in opposite directions

The impulses of Mars and unpleasant Aquilons. ${ }^{49}$

Even such a description of the relationship between God and the faithful, objectified by the introduction of a pair of characters to the text, has been marked with an individual accent. Receiving divine teachings, presented in the engraving as taking notes from academic lectures, was interpreted in symbolic order as carving them deep inside the heart with a love blade. In this way, the exegesis contained in the poetic subscriptio is not only placed in the context of the popular

${ }^{48}$ A print in the collection of the Ethnographic Museum in Cracow, inventory no. 44813.

${ }^{49}$ A print in the collection of the Ethnographic Museum in Cracow, inventory no. 44814 . 
cordial emblematics, ${ }^{50}$ but also clearly takes care to mark the interpretation of the pictura with a personal stamp of intimate experience of the revealed truths.

The poetic subscriptiones written in Galle's drawings with a skilled hand, also reveal literary familiarity. Their creator was perfectly conversant with the poetics of the genre whose content spans from the description of the pictura to the meanings suggested by the lemma. But his subscriptiones have not only the value of literary curiosity. These short lyrical forms also reveal his technical proficiency, which allows us to juxtapose the tetrastich of the anonymous author with the religious emblems of Baroque poets, both known and recognised.

Translated from Polish by Kaja Szymańska

\section{Bibliography}

\section{Primary sources}

Birkowski, F., "O świętych obrazach, jako mają być szanowane, kazanie”, in Birkowski, Głos krwie B. Jozafata Kuncewicza, Cracow 1629.

Czechowic, M., Zwierściadłko panienek chrystyjańskich, ed. K. Meller and D. Chemperek, Warsaw 2011.

Graduał karmelitański z 1644 roku o. Stanisława ze Stolca, ed. T. Chrzanowski and T. Maciejewski, Warsaw 1976.

Grochowski, S., Wiersze i inne pisma co przebrańsze, ed. K. J. Turowski, Cracow 1859. The Holy Bible: New International Version, transl. and published by International Bible Society, verified edition, Nashville and London 2011, available online at biblegateway.com (accessed on 17 Oct. 2019).

${ }^{50}$ Cf., inter alia: K. A. Wirth, "Religiöse Herzemblematik", in Das Herz, vol. 2: Im Umkreis der Kunst, Frankfurt am Main 1966, pp. 83-105; A. Sauvy, Le miroir du cour. Quatre siècles d'images savantes et populaires, Paris 1989; T. A. Campbell, The Religion of the Heart: A Study of European Religious Life in the Seventeenth and Eighteenth Centuries, Columbia 1993; cf. also: C. Drążek, "Rozwój kultu Serca Jezusowego w Polsce", in Bóg bliski. Historia i teologia kultu Najświętszego Serca Jezusa, ed. C. Drążek and L. Grzebień, Cracow 1983, pp. 94-102. 
Hugo, H., Pia desideria emblematis, elegiis et affectibus S[ancti] Patrum illustrata, Antwerp 1624.

Hugo, H., Pobożne pragnienia, [Polish translation by J. K. Żaba, Supraśl] 1744.

Hugo, H., Pobożne pragnienia, transl. B. Ostrzykowski, Warsaw 1843.

Hugo, H., Pobożne żądania, transl. J. K. Żaba, Vilnius 1754.

Kwiatkiewicz SJ, J., Roczne dzieje kościelne od Roku Pańskiego 1198 aż do lat naszych, Kalisz 1695.

Lacki, A. T., Pobożne pragnienia, ed. K. Mrowcewicz, Warsaw 1997.

Mieleszko, M., Emblematy, ed. R. Grześkowiak and J. Niedźwiedź, Warsaw 2010.

Miłości Boskiej i ludzkiej skutki różne. Wraz z siedemnastowieczna polską wersja tekstów do „Amoris divini et humani effectus varii”, ed. J. Pelc and P. Pelc, Warsaw 2000.

Morsztyn, Z., Emblemata, ed. J. Pelc and P. Pelc, Warsaw 2001.

Potocki, W., Pojedynek rycerza chrześcijańskiego, MS 5888/I in the Library of the Ukrainian Academy of Sciences (collection of Ossolineum).

Potocki, W., "Pojedynek rycerza chrześcijańskiego", in J. T. Trembecki, Wirydarz poetycki, ed. A. Brückner, vol. 2, Lviv 1911, pp. 74-78.

Potocki, W., Rozbój duchowny na drodze zbawiennej, MS IV.3047 in the National Library in Warsaw.

Potocki, W. "Rozbój duchowny na drodze zbawiennej”, in J. Malicki, "Wacława Potockiego Rozbój duchowny", in Miscellanea staropolskie, vol. 5, ed. T. Ulewicz, Wrocław 1980, pp. 247-248.

"Relacyja poselstwa księcia Zbaraskiego do Turek in Anno 1623", in L. Rogalski, "Poselstwo Krzysztofa księcia Zbaraskiego do Turcji w roku 1622", Dziennik Wileński 3 (1827), p. 273.

Twardowski, K., Łódź młodzi z nawatności do brzegu plynąca, ed. R. Grześkowiak, Warsaw 1998.

Twardowski, S., Przeważna legacyja Krzysztofa Zbaraskiego od Zygmunta III do soltana Mustafy, ed. R. Krzywy, Warsaw 2000.

Vaenius, O., Amoris divini emblemata, Antwerp 1615.

Vaenius, O., Amorum emblemata, figuris aeneis incisa, Antwerp 1608.

[Zbiór] wierszów polskich kompozycyj ..., które się w pokojach złotyjowskich znajduja pod temi figurami, które się niżej wyrażają, d[ie] 6 Julii, Anno Domini 1753 (MS 5284/I in the collection of the Ossolineum in Wrocław).

\section{Secondary sources}

Borkowska, M., Panny siostry w świecie sarmackim, Warsaw 2002.

Borkowska, M., Życie codzienne polskich klasztorów żeńskich w XVII-XVIII wieku, Warsaw 1996.

Buchwald-Pelcowa, P., “Typologia polskich książek emblematycznych”, Barok 3 (1996), no. 1. 
Buschhoff, A., Die Liebesemblematik des Otto van Veen. Die „Amorum Emblemata“ (1608) und die „Amoris Divini Emblemata“ (1615), Bremen 2004, pp. 179-258. Campbell, T. A., The Religion of the Heart: A Study of European Religious Life in the Seventeenth and Eighteenth Centuries, Columbia 1993.

Chrościcki, J. A., "Horatius Sarmaticus. Dwa antwerpskie wydania Lyricorum Sarbiewskiego z frontyspisami według projektów Rubensa", in O ikonografii świeckiej doby humanizmu. Tematy - symbole - problemy, ed. J. Białostocki, Warsaw 1977, pp. 281-333.

Chrościcki, J. A., "Między Wilnem, Rzymem i Antwerpią. O dwóch projektach P. P. Rubensa do sześciu wydań „Lyricorum libri IV” Macieja Kazimierza Sarbiewskiego w Offcina Plantiniana", Roczniki Humanistyczne 50 (2002), no. 4, pp. 99-126.

Chrościcki, J. A., "Peter Paul Rubens a Maciej Kazimierz Sarbiewski”, Ciechanowskie Zeszyty Literackie 10 (2008), pp. 105-114.

Cubrzyńska-Leonarczyk, M., Katalog druków supraskich, Warsaw 1995.

Daly, P. M. and G. R. Dimler, The Jesuit Series, vol. 3, Toronto 2002.

Dietz, F., E. Stronks, and K. Zawadzka, "Roomskatholieke Pia desideria - bewerkingen in internationaal perspectief", Internationale Neerlandistiek 47 (2009), no. 3, pp. 31-49.

Drążek, C., "Rozwój kultu Serca Jezusowego w Polsce", in Bóg bliski. Historia i teologia kultu Najświętszego Serca Jezusa, ed. C. Drążek and L. Grzebień, Cracow 1983, pp. 94-102.

Gomulicki, W., "Zapomniana poetka polska z wieku XVIII-go", in W. Gomulicki, Kłosy z polskiej niwy, Warsaw 1912, pp. 289-384.

Grześkowiak, R., "Wprowadzenie do lektury", in K. Twardowski, Łódź młodzi z nawałności do brzegu plynąca, ed. R. Grześkowiak, Warsaw 1998.

Grześkowiak, R. and J. Niedźwiedź, "Wstęp", in M. Mieleszko, Emblematy, ed. R. Grześkowiak and J. Niedźwiedź, Warsaw 2010.

Hałoń, J., "W poszukiwaniu źródeł inspiracji, czyli o dwóch polskich wersjach Pia desideria Hermana Hugona", Roczniki Humanistyczne 50 (2002), no. 1, pp. 127-159.

Hałoń, J., "Wobec obrazu”, Zeszyty Naukowe KUL 46 (2003), no. 1-2, pp. 33-61. Hollstein's Dutch and Flemish Etchings, Engravings and Woodcuts 1450-1700, vol. 66: The Wierix Family, part 8, comp. Z. van Ruyven-Zeman and M. Leesberg, ed. J. van der Stock and M. Leesberg, Rotterdam 2004.

Inspiracje grafika europejska w sztuce polskiej. Czasy nowożytne, ed. K. MoisanJabłońska and K. Pomian, Warsaw 2010.

Keferstein, H. and B. Wojczulanis, "Polska wersja rękopiśmienna emblematów Georgette de Montenay", Komunikaty Mazursko-Warmińskie 3 (1967), pp. 518-522.

Ławniczak, G., "Emblematy haftowane symbolizujące życie św. Franciszka Salezego na barokowych antependiach z kościoła SS. Wizytek w Warszawie", Barok 8 (2001), no. 2, pp. 59-73.

Marcinowska, M., Dwór pełen barw. Architektura i dekoracja malarska dworu z Rdzawy w Sadeckim Parku Etnograficznym, Nowy Sącz 1997. 
Marcinowska, M., "Emblematy ze ścian dworu z Rdzawy w Sądeckim Parku Etnograficznym”, Rocznik Sadecki 37 (2009), pp. 166-167.

Moisan-Jabłońska, K., Obrazowanie walki dobra ze złem, Cracow 2002.

Moisan-Jabłońska, K., "Uwagi nad metodologią badań ikonografii sztuki kościelnej dobry kontrreformacji”, Biuletyn Historii Sztuki 50 (1988), no. 4, pp. 335-340.

Moisan-Jabłońska, K., "Wprowadzenie”, in M. Pielas, Matka Boska Bolesna, Cracow 2000, pp. 5-13.

Mrowcewicz, K., "Wprowadzenie do lektury”, in A. T. Lacki, Pobożne pragnienia, ed. K. Mrowcewicz, Warsaw 1997, pp. 9-12.

Muczkowski, J., Bractwa jezuickie i akademickie w Krakowie, Cracow 1845.

Nawrocka-Berg, M., "Osiemnastowieczny Żywot serafickiej panny Teresy świętej ze zbiorów sióstr karmelitanek bosych”, Barok 12 (2005), no. 2, pp. 145-156.

Pelc, J., Słowo i obraz. Na pograniczu literatury i sztuk plastycznych, Cracow 2002.

Pelc, J. and P. Pelc, "Wstęp”, in Morsztyn, Emblemata, ed. J. Pelc and P. Pelc, Warsaw 2001.

Pfeiffer, B., “'Pobożne pragnienia' Aleksandra Teodora Lackiego - pierwszy polski przekład utworu emblematycznego Hermana Hugona Pia desideria”, Ze Skarbca Kultury 44 (1987), pp. 9-43.

Pollak, R., "Emblematy Anonima z początków XVII w.", in Miscellanea literackie, vol. 2, ed. R. Pollak, Wrocław 1966, pp. 110-131.

Roćko, A., "Wizerunek artystyczny Antoniny Niemiryczowej”, in Pisarki polskie epok dawnych, ed. K. Stasiewicz, Olsztyn 1998, pp. 129-140.

Sauvy, A., Le miroir du cœur. Quatre siècles d'images savantes et populaires, Paris 1989.

Sebastián, S. L., "La visión emblemática del amor divino según Vaenius", Cuadernos de arte de la Fundación Universitaria Española 2 (1985), pp. 3-51.

Selling, M., "Galle Cornelis" (1-3), in Saur Allgemeines Künstlerlexikon. Die bildenden Künstler aller Zeiten und Völker, vol. 48: Gallarini-Garcha, Munich and Leipzig 2006, pp. 8-9.

Skoczeń-Marchewka, B., Cor Jesu Amanti Sacrum - obiekt tygodnia: kwiecień/2, http://www.etnomuzeum.eu/Obiekty,6_cor_jesu_amanti_sacrum_obiekt_tygodnia_kwiecien2.html (accessed on 1 Jan. 2011).

Skorupa, A., "O obrazach na parapecie chóru kościoła św. Katarzyny w Nowym Targu”, Almanach Nowotarski 10 (2006), pp. 128-133.

Thøfner, M., "'Let your desire be to see God': Teresian Mysticism and Otto van Veen's Amoris Divini Emblemata", Emblematica 12 (2002), pp. 83-103.

Walicki, M., "Ludowy refleks sztuki Callota", in Walicki, Obrazy bliskie i dalekie, Warsaw 1972, pp. 252-264.

Wirth, K. A., "Religiöse Herzemblematik", in Das Herz, vol. 2: Im Umkreis der Kunst, Frankfurt am Main 1966, pp. 83-105.

Wisłocki, M., Sztuka protestancka na Pomorzu 1535-1684, Szczecin 2005.

Wisłocki, M., "Zur Rezeption jesuitischer Ideen in der evangelischen Frömmigkeit und Kirchenkunst Pommerns”, in Jesuitische Frömmigkeitskulturen. Konfessionelle Interaktion in Ostmitteleuropa 1570-1700, ed. A. Ohlidal and S. Samerski, Stuttgart 2006. 
